\title{
Missing and Missed: \\ Rehumanisation, the Nation and Missing-ness
}

\author{
NICKY ROUSSEAU, RIEDWAAN MOOSAGE AND CIRAJ RASSOOL \\ Department of History, University of the Western Cape
}

The bringing together of two lines of research that have previously been treated separately - namely the missing/missed body of apartheid-era atrocities and the racialised body of the colonial museum - animates this issue of Kronos. Both the skeletons of empire and those of apartheid-era atrocities can be thought of as racialised, and as 'disappeared' and missing. Furthermore, both areas are marked by similar lines of enquiry, linked to issues of identification, redress and restoration, often framed through notions of humanisation or rehumanisation. Consequently, these different

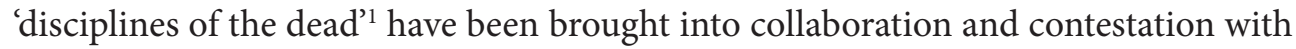
each other, with missingness often reproduced through the ways in which the dead have been drawn into grand narratives of the nation and its seeming triumphs over colonialism and apartheid.

Notwithstanding their similarities, the racialised body of the colonial museum and the body of more recent conflicts have their own genealogies and literatures. The 'disappeared' entered the political lexicon of terror largely through Argentina and Chile; two decades later Rwanda and Bosnia turned international attention to mass violence and genocide as exemplified by the mass grave. South Africa slips through these grids: apartheid security forces tried but failed to emulate their Latin American counterparts in 'disappearing' activists on a large scale, while inter-civilian violence, which mostly took the form of political rather than ethnic, racial or religious cleansing, did not produce mass graves. Nonetheless, both 'disappearances' and inter-civilian conflict produced missing persons in the South African conflict - most presumed dead, and thus, as Madeleine Fullard describes them (this issue) 'in limbo - dead, but missing. Investigations into such cases, led first by the country's Truth and Reconciliation Commission (TRC), and later by its Missing Persons Task Team (MPTT), sought to locate, exhume, identify and return mortal remains to their families. In so doing, South Africa joined a growing list of countries following this route.

Except perhaps in the United States, the practice of valorising the remains of the 'unknown soldier' - the unidentified dead of battle - has given way to a questioning of practices that allow the dead of war and conflict to be buried where they fall in marked or unmarked graves. Where cenotaphs mark the presence of an absence, and came to stand for all those who did not return, ${ }^{2}$ this has shifted to a focus on

Thanks to our two anonymous reviewers for their thoughtful and rigorous reading provided at such short notice.

1 C. Rassool, 'Human Remains, the Disciplines of the Dead, and the South African Memorial Complex', in D. R. Peterson, K. Gavua and C. Rassool (eds), The Politics of Heritage in Africa: Economies, Histories, and Infrastructures (New York: Cambridge University Press, 2015), 133-156.

2 T. Laqueur, 'Memory and Naming in the Great War' in J. R. Gillis (ed.) Commemorations (Princeton, NJ: Princeton University Press, 1994), 155-164. 
the unidentified and untraced dead. Although the very forms of mass violence, and practices of 'disappearing' or displacing civilians (rather than soldiers), have proliferated, undergirding this growth, something else is arguably at work. Contemporary practices of dealing with the missing dead are distinguished by the way in which corporeal matters have risen to the fore, encountering wider discourses of witnessing and speaking out associated with truth-telling and human rights initiatives, and producing what Ciraj Rassool suggests is a 'moment of return'. This moment also signals significant affective shifts in how death - particularly unjust death - should be addressed in the aftermaths of violence and war. So powerful is this moment of return that it evokes retrospective force, as evidenced by continuing work arising from the conflicts in Spain (from 1936 to 1939) and Cyprus (in the 1960s and 1970s). ${ }^{3}$ Practices of exhumation, previously directed towards the requirements of forensic evidence, are now frequently associated with forms of reparation and return.

The moment of return also resonates with earlier calls to restitute skeletal remains from museum and university collections associated with colonialism and empire. The dead body of the warrior, especially his or her missing and stolen parts, are key historical tropes of colonial conquest, with stories of heroic suicides, corpses defiled and dismembered, heads separated from bodies and transported across land and sea to Europe. The quest to recover and return the heads of such warriors stands as a significant effort to reverse legacies of conquest. ${ }^{4}$ Another strand of research is that of German colonials preparing and exporting the remains of Namibian people from concentration camps - a history of confinement and defilement from the early 1900s, which is regarded as a precursor to the Holocaust. ${ }^{5}$ This was one context for researching the stolen and traded skeletons of racial science that were significant for museum development in Europe and South Africa at the turn of the twentieth century. The work of researching the journeys of the violated dead from buried persons to museum objects can also be seen as a forensic enquiry.

Exhumation teams and professional agencies have stakes in this moment of return. As Lore Colaert puts it, 'forensic anthropology has ... ambitions as well', suggesting that more than a response to a demand, forensic anthropology is a driver of the shift from practices of letting bones lie to the moment of return. ${ }^{6}$ Colaert's reference to forensic anthropology implicates scholars as well. Indeed, the boundaries between activism, professional teams and scholarship are blurred, and we ourselves are not exempt, since we have argued for an activist practice of history and historicising in the public, which transcends the limited frames of social and popular history.

3 L. Renshaw, Exhuming Loss: Memory, Materiality and Mass Graves of the Spanish Civil War (Walnut Creek, CA: Left Coast Press, 2015); P. Sant Cassia, Bodies of Evidence: Burial, Memory and the Recovery of Missing Persons in Cyprus (New York: Berghan, 2007).

4 P. Hayes, 'Order Out of Chaos: Mandume Ya Ndemufayo and Oral History', Journal of Southern African Studies, 19, 1, March 1993, 89-113; P. Lalu, The Deaths of Hintsa: Post-Apartheid South Africa and the Shape of Recurring Pasts (Cape Town: HSRC Press, 2009); L. White, 'The Traffic in Heads: Bodies, Borders and the Articulation of Regional Histories,' Journal of Southern African Studies, 23, 2, June 1997, 325-338.

5 C. W. Erichsen, 'The Angel of Death Has Descended Violently Among Them': Concentration Camps and Prisoners-of-War in Namibia, 1904-08 (ASC Research Report 79; Leiden: African Studies Centre, 2005); D. Olusoga and C. W Erichsen, The Kaiser's Holocaust: Germany's Forgotten Genocide and the Colonial Roots of Nazism (London: Faber and Faber, 2010).

6 L. Colaert, 'Excavating a Hidden Past: The Forensic Turn in Spain's Collective Memory' in M.T. Starzmann and J. R. Roby (eds), Excavating Memory: Sites of Remembering and Forgetting (Tallahassee: University Press of Florida, 2016), 336-356, at 340. 
Pertinent here are Nicky Rousseau's long involvement in the TRC and the MPTT, and Rassool's very active involvement in driving policies and processes of repatriation. In short, representing the moment of return as a spontaneous wave of survivors, families - second or third generation - can function as a narrative that disguises other agencies in shifting or producing particular cultural sensibilities.

A growing scholarly literature has accompanied these developments. The Forensic History Project, ${ }^{7}$ was initiated at the University of KwaZulu-Natal and relocated to the University of the Western Cape (UWC) in 2015 where Rousseau, Riedwaan Moosage and Bianca van Laun were engaged in similar research. Shifting to a more conceptual focus - although always within shouting distance of the work being done by the MPTT - we extended an existing reading group on materialities and corporealities of violence, and this became the heart of what the Forensic History Project is now, enabling the development of a research hub, and drawing in students from senior undergraduate to doctoral level. ${ }^{8}$

We set to work by engaging the political contexts of missing persons in South Africa, and the TRC and MPTT's work. Research interests quickly settled around the afterlives of the missing and dead, rather than the contexts of going or being rendered missing. Accordingly, the afterlives of being missing and missed forms one line of enquiry. Here Jenny Edkins' work - especially her emphasis on counting and accounting for each missing and missed person, the irreplaceable 'person-as-such', and on how the missing configure contemporary politics - resonated strongly. ${ }^{9} \mathrm{~A}$ second line of enquiry, influenced by earlier reading on the corporealities of violence through the work of the Bodies of Mass Violence and Genocide research project and the Bones Collective, focuses on debates regarding the agency and governmentalities of the dead body, its 'emotive materiality' and 'affective presence' beyond political frames of the nation, as well as the 'vitality and efficacy' of its 'substances.'10 A third line of study was inspired by Katherine Verdery's evocative phrase, 'the political lives of dead bodies', which speaks to the afterlives of unsettled death in South Africa. ${ }^{11}$

We were struck by the curious paucity of historians working in this field. How was it that issues in which the work of the past and memory work were so central seemed to have slipped through history's grids? In response to this provocation, the question of the disciplines of the dead became another site of enquiry, and we turned to the naming of our project, the Forensic History Project. We had not chosen this

7 Thembisa Waetjen and the late John Daniel, a former TRC researcher, initiated the project, funded by South Africa's National Research Foundation. Its full title was 'Forensic History: Investigating Political Killings and the 'Disappeared' in South Africa, 1990-1994.'

8 Dissertations completed by senior postgraduate students at UWC include B. N. Abrahams, 'Unfinished Lives: The Biographies of Nokuthula Simelane', (MA thesis, 2018); B. van Laun, 'Administrative Death: Bureaucracy, Capital Punishment and Governmentality in South Africa during the 1960s' (PhD dissertation, 2018); R. Moosage, 'Missing-ness, History and Apartheidera Disappearances: The figuring of Siphiwo Mthimkulu, Tobekile 'Topsy' Madaka and Sizwe Kondile as missing dead persons' $(\mathrm{PhD}$ dissertation undertaken in association with the Vrije Universiteit, Amsterdam, forthcoming 2019); and R-L. Karating, 'Exhumations, Reburials and History Making in Post-Apartheid South Africa' (MA thesis, forthcoming, 2019).

9 J. Edkins, Missing: Persons and Politics (Ithaca, NY: Cornell University Press, 2011).

10 The former project was led by genocide scholars, Elisabeth Anstett and Jean-Marc Dreyfus. The last in the three-volume series co-edited by them is reviewed in this issue by Sophie Schasiepen. The Bones Collective is an interdisciplinary research network initiated by scholars at Edinburgh University, including Joost Fontein, a contributor to this issue. See http://www.san.ed.ac.uk/ research/research_themes/bones_collective (accessed 23 January 2019).

11 K. Verdery, The Political Lives of Dead Bodies: Reburial and Postsocialist Change (New York: Columbia University Press, 2000). 
name; located in the forensic, its seeming gesture to a positivist evidentiary mode, troubled us. In thinking the question of forensic history, and thus history's place in the disciplines of the dead (conventionally deemed to be human biology, archaeology and physical anthropology, marked often in the past by colonial frames of race and typology), we sought to work towards a critical and conceptual understanding of what this entails.

An encounter with the work of the Forensic Architecture research group at Goldsmiths, University of London, took our enquiry into the etymology and genealogy of the term, forensis. ${ }^{12}$ This yielded a more indeterminate idea of the 'missing person', and of the ways that institutions, instruments, scholarly disciplines, and modes of governmentality (through which the missing person was categorised and recovered) often attempt to shore up indeterminacy. As Forensic Architecture points out, attending to the genealogy of forensis surfaced a forgotten meaning, that is: of, or pertaining to a forum. This suggested a more contested space of debates, disputes, and questions, which in turn destabilises the evidentiary fields of the forensic. Reinstating the forensic as also and always a forum resonated with our methods and thinking. ${ }^{13}$

Reading the disciplines of the dead through the forensic also produced an encounter with another site of research in our department, namely that by Rassool and the late Martin Legassick. Their research on collections of human remains in public and university medical museums revealed a substantial and unethical acquisition through theft and trade, that was put to work for the purposes of the emerging field of racial science in the early twentieth century. ${ }^{14}$ Initially, research on museums and their skeletal collections and the missing dead of apartheid era atrocities were conceptualised as separate projects. Yet we realised that these mortal remains encountered each other in the same laboratories where physical anthropology, now recast as forensic anthropology, performed the work of identification. The developing modalities of repatriation drew significantly from the return and reburial practices of the TRC and MPTT. We began to realise that South Africa is in a unique position where the dead of apartheid atrocities intersects with museums' skeletal collections in deeply complex and productive ways. When Rassool joined the Forensic History Project, we sought to deepen this encounter, returning to our earlier engagements with corporeality and materiality, agency, presence and absence, politics and history. This time, we asked cross-cutting questions about personhood, re/humanisation and restoration, sounding these across both colonial and apartheid settings. In so doing, we sought to articulate the notion of missing-ness, introduced to us (but not conceptualised) by Edkins. The concept is one with which many of us are still grappling, and which we invoke as a question (with all its implications) across both colonial and apartheid settings.

12 Forensic Architecture, Forensis: The Architecture of Public Truth (Berlin: Sternberg Press, 2014).

13 If we had to identify one defining feature of UWC's history department since the early 1990s, it would be its commitment to a critical history, located in the public, where scholarly discipline was one site of historical production in a disputatious civic forum. See J. R. Forte, P. Israel and L. Witz (eds), Out of History: Re-imagining South African Pasts (Cape Town: HSRC Press, 2017).

14 M. Legassick and C. Rassool, Skeletons in the Cupboard: South African Museums and the Trade in Human Remains 1907-1917 (South African Museum, 2000). 
As a way of introducing this special issue of Kronos, we trace our conceptual development through the years and reflect on some of the debates that animated the two workshops to which the contributors to this issue respond. ${ }^{15}$ While the concepts we explore are entangled, for the sake of legibility, we attempt a slight loosening of the knots in order to trace our itineraries.

\section{Thinking the forensic}

Much of the scholarly concern with the fate of dead bodies of atrocity has focused on their instrumentalisation, both by perpetrators and through subsequent material, symbolic and political efforts to recuperate such remains. Elisabeth Anstett and Jean-Marc Dreyfus pose the questions, why exhume and why identify? In response, they suggest two critical contexts. Firstly, national politics on amnesty and memory, conditioned by the international politics of transitional justice. Secondly, 'unique and complex social contexts that allow ... or else prevent ... the search for victims' remains. ${ }^{16}$ Such contexts include the recent rapid development of techniques and technologies of search and identification. While the Argentine Forensic Anthropology Team (EAAF) was established in 1984 to collect forensic evidence of the tactic of 'disappearing' widely used in Argentina's 'dirty war', it is now but one of numerous such teams and initiatives across the globe. The much-publicised exhumations in former Yugoslavia and Rwanda (beginning in the late 1990s), followed by the searching for, identifying and returning of 9/11 remains in the United States further enabled this global trend. ${ }^{17}$ Although, as Moosage reminds us, 'this quick expansion ... is framed by legal, historical and humanitarian objectives that often compete with one another, ${ }^{18}$ a convergence of these contexts has produced what is referred to as a 'forensic turn'.

While Anstett and Dreyfus evoke a normative concept of forensics, namely a claim to the application of scientific methods of establishing evidence, Eyal Weizman proposes forensics as 'public truth ... public claims that can be made on behalf of objects/spaces in forums such as courts or other publics..$^{19}$ Instating publics through forensics' earlier etymology draws attention to two separate, though intertwined, moments. The first is that of the field - the material site or body - from which evidence of violence is deduced. Notably, the 'forensic turn' has been characterised by the increasing appearance of material objects - human remains, sites, buildings - as witnesses. Shela Sheikh (this issue) extends this notion of the witness, challenging the

15 See the Editorial Note (this issue).

16 Anstett and Dreyfus, 'Introduction: Why Exhume? Why Identify?' in Human Remains and Identification: Mass Violence, Genocide and the Forensic Turn, (Manchester: Manchester University Press, 2015), 1-13, at 5.

17 See for example, Z. Crossland, 'Evidential Regimes of Forensic Archaeology', Annual Review of Anthropology, 42 (2013), 121-137; C. Moon, 'Human Rights, Human Remains: Forensic Humanitarianism and the Human Rights of the Dead' in UNESCO (Wiley: Oxford, 2016), 50-63; A. D. Alonso, P. D. Galbraith and B. Nienass, 'Bringing the Dead Back into Society: An Interview with Mercedes Doretti', Social Research, 83, 2, 2016, 511-534; A. Rosenblatt, Digging for the Disappeared: Forensic Science After Atrocity (Stanford University Press: Stanford, California, 2015); and I. Rojas-Perez, Mourning Remains: State Atrocity, Exhumations, and Governing the Disappeared in Peru's Postwar Andes (Stanford University Press, 2017).

18 Moosage, 'Missing-ness', 58.

19 Quoted in T. Keenan, 'Getting the Dead to Tell Me What Happened: Justice, Prosopopoeia, and Forensic Afterlives' in Forensic Architecture, Forensis: The Architecture of Public Truth, (Berlin: Sternberg Press, 2014), 35-55, at 35, emphasis added. 
ways in which we 'conceive of the witness, ontologically (across various forms of life and temporalities), epistemologically and politically'. However, such witnesses cannot speak for themselves, but require mediants to speak on their behalf. Here, the introduction of mediants and their interpretive labour signals, as Thomas Keenan suggests (this issue), 'a fundamental lack of absolute certainty' at the heart of the forensic, thus necessitating the second moment - that of the forum. Weizman and Keenan describe the capacity of materiality to register evidential traces, as well as the rhetorics associated with the forum, as 'forensic aesthetics. ${ }^{20}$

For Forensic Architecture, this evidential uncertainty does not negate but instead intensifies the need for investigative forensic work, while at the same time maintaining a commitment to 'critical reflection on the terms by which contemporary forensic investigations ... are currently undertaken'. Understanding the field as more than a physical location or body, "but itself a dynamic and elastic territory, a force field that is shaped by but also shapes conflict', blurs the boundaries of the animate and inanimate, human and object, requiring a rethinking of agency. Correspondingly, widening and understanding the forum as 'a gathering of political collectives' opens the potential of the forensic 'as a political practice. ${ }^{21}$

This potential, encapsulated in the notion of counter-forensics, was first articulated by Allan Sekula. Keenan offers two understandings of counter-forensics: the first is pre-emptively impeding the discovery of evidence to prevent future analysis of material traces; the second is its opposite, deploying 'forensic techniques as a practice of "political maneuvering", as a tactical operation in collective struggle."22 This latter meaning is at the core of the forensic 'as a political practice.' 'Political maneuvering', a phrase taken from Sekula, is a commitment to a forensic sensibility in which presenting material evidence in various forums acts to persuade and convince, but more so, opens a space to question and challenge the very production of such evidence. In other words, 'political maneuvering' in relation to the reading and presenting of evidence is such that it is 'up for grabs' in so far as 'everything beyond the imprinting of a trace, is up for grabs. ${ }^{23}$

It is in this sense that Sekula draws a resonance between the work of photography, with its 'incapacity for abstraction', and that of forensic experts in exhuming and identifying human remains. This resonance is expressed through a 'sequence of actions' that Sekula identifies as 'Identification-Annihilation-Identification'. For Sekula, 'forensic methods ... offer a tool for oppressive states' as well as 'tools for opposition. He writes:

[The] oppressor state catalogues its victims as precisely as possible, typing them as a group, but seeking to register and track individual members. The

T. Keenan and E. Weizman, Mengele's Skull: The Advent of a Forensic Aesthetics (Berlin: Sternberg Press, 2012). The concept of forensic aesthetics brought us into productive conversation with Patricia Hayes, National Research Foundation Chair in Visual History and Theory, and with the research platform on Politics and Aesthetics headed by Heidi Grunebaum at the Centre for Humanities Research, both at UWC.

21 E. Weizman, 'Introduction' in Keenan and Weizman, Mengele's Skull, 9.

22 T. Keenan, 'Counter-Forensics and Photography', Grey Room, 55, Spring 2014, 58-77, at 69.

23 Sekula quoted in Keenan, 'Counter-Forensics', 66-67. 
key to ideological power over the 'other' lies in typing: the key to functional power lies in individuation. In other words, stereotypes are ideologically useful and necessary, but in the end it is individuals who must be reduced to ashes ... Counter-forensics then, understood as the exhumation and identification of the 'anonymized' (disappeared) bodies of the oppressor state's victims, becomes the key to a process of political resistance and mourning. ${ }^{24}$

However, as Keenan notes, 'just as the forensics is different when linked to a process of political resistance to oppression, so is the identification. Assigning names and histories after the event of annihilation is something very different from fixing identities before it.' The resonance between photography and the 'dismal science of mass-grave exhumation in the project of recording and recovering the traces of the disappeared, of reindividuation' is such that both projects share a humanism, but one that, as Keenan underscores, 'is neither the merely sentimental and compassionate kind nor a mask of domination, but a basic one, basic precisely to the extent that it refers not to abstract metaphysical foundations but rather to the traces of specific individuals and events, the testimony of the bones and the images. ${ }^{25}$

Counterintuitively, rethinking forensics along the lines suggested by Forensic Architecture was crucial in enabling the encounter between apartheid-era and colonial dead. Counterintuitive, because the politics of the latter had refused the forensic, entangled as it was with racial science via physical anthropology. In contrast, the MPTT had a very strong sense of the necessity of (normative) forensic practice owing to several misidentifications of remains by the TRC. Forensic Architecture's reintroduction of the forum into the understanding of forensics opened a space in which to rethink and accept Sekula's challenge 'to help prevent the cancellation of that testimony [in all its iterations] by more authoritative and official texts. ${ }^{26}$ Yet, as Van Laun (this issue) demonstrates, and as we have come to understand, testimony that a counter-forensic practice enables also has the potential to run up against what might be seen as a limit. This limit sees the figuring of both the missing/missed body of apartheid atrocities and the racialised body of the colonial museum caught in ongoing critiques about the ways in which they are appropriated into the postapartheid nation.

\section{Missing and missed and the South African nation}

That the dead figure in the nation is hardly a new development, as is documented in multiple historical and contemporary settings. South Africa is no exception. However, long histories of colonial and racial subjugation have configured the place and the naming of dead in the post-apartheid nation in very particular ways.

24 Sekula quoted in Keenan, 'Counter-Forensics', 70.

25 Keenan, 'Counter-Forensics', 72.

26 Sekula cited in Keenan, 'Counter-Forensics', 73 
'What's in a name?' asks Jane Taylor (this issue). Later we will answer, 'everything, as a name -identification - enables the return of this person. We note here the difficulties we have had in appropriately specifying and naming the missing dead of whom we write. These difficulties are more than a search for appropriate descriptive terms, but raise issues of ontology, law, history and politics. They also index the instability of death (rather than its finality) and the impossible uncertainty of missingness evoked in several articles in this issue (Taylor, Vilho Shigwedha, Fullard and Keenan).

For missing persons, the ontological question of whether they are alive or dead, and the multiple ontologies of being, is at the heart of the uncertainty that missingness and death itself produces (Joost Fontein, this issue). The answer to this ontological question is by no means a simple matter. It is easy to understand that for families of those rendered missing, this question can only be answered by locating a live person or producing a dead body. Yet the polysemy of death and its afterlives no longer make confirmation of a death sufficient, and is partly responsible for the break from previous practices of allowing the dead of war and violence to lie in graves distant from home. For skeletons of empire, their ontological status as dead enabled their transmutation from subject to object, human to nonhuman. Indeed, this transmutation rested on a prior ontological classification within physical anthropology of those named as bushmen, as prehuman 'living fossils', a specific classification imposed on various southern Africans, during a phase of anxiety about 'extinction' in the early $1900 \mathrm{~s}^{27}$ The bushman body was cast as a recovered object of a primitive racial type doomed to inevitable extinction and encrustation in rock. Moreover, the question of what constitutes a body has emerged with force in this moment of return where mortal remains may have disintegrated over time or been disarticulated - mutilated or fragmented at death - and commingled in mass graves, located across multiple graves (as in former Yugoslavia), or eaten by predators.

Of course, these are not merely ontological questions, they are also legal; what constitutes a person is a matter of law. Law also frames and categorises the missing. We suggested earlier that the missing entered the political lexicon as 'disappeared' through the tactic of 'disappearing' political opponents, associated particularly with Latin American dictatorships. The 'disappeared' person - with scare quotes to indicate that some perpetrator knows their fate and can end this state of missingness - configured and arguably overdetermined what it means to be missing in political conflict, ${ }^{28}$ even though war and violence have always routinely produced vast numbers of unidentified bodies and displaced persons. More recently, 'disappearance' has been inflected through human rights law as a specific category within gross violations of human rights, named as 'enforced disappearance. This categorisation enabled its codification and institutionalisation in international governance in the form

27 This anxiety was evident in the presidential address given by A. C. Haddon to the Anthropological Section of the Conference of
the British Association for the Advancement of Science held in South Africa in August and September 1905. See Legassick and
Rassool, Skeletons, 3.
28 S. Robins cited in Karating, 'Exhumations,' 17. 
of a United Nations protocol and a special rapporteur. Once translated into a legal category, disappearance lost its scare quotes as well as some of its political charge. Other forms of making missing associated with war and political violence, such as displacement or missing combatants, also sometimes fall under the purview of international humanitarian law, governed by the Geneva Convention.

The trace of the legal framework is evident in other classificatory regimes, with their own forms of inclusion and exclusion. In inheriting the form of the truth commission from Latin America, the South African TRC also inherited the category of enforced disappearance, glossed as abduction, even though this was by no means the dominant category of persons reported missing to the TRC. Abduction as a category of gross human rights violation was often accompanied by other mandated gross violations (such as torture, killing or severe ill-treatment). Thus, despite the many other ways a person could go missing in political circumstances (also a requirement of the TRC's mandate) - for example, missing in exile or displaced by violence - the TRC ruled such cases out of its mandate, unless investigation confirmed that the missing person could also be categorised under a different gross violation. Missing persons were thus coded and re-coded through these quasi-judicial and juridical categories, which could include the 'associated violation' of 'violating a corpse after death' ${ }^{29}$ thus ontologically and legally enacting a separation between a person and their mortal body. At its closure, the TRC recommended that a task team be established to continue investigation into the fate of 477 unsolved missing persons, resulting in the subsequent establishment of the MPTT.

Separating those who counted (and were thus named) from those who fell outside the TRC's mandate produced other forms of categorisation that acted to include or exclude. Legally, the TRC's temporal mandate (delineated as 1960 to 1994) also determined who counted, as did a particular definition of political violence that privileged bona fide political organisations. This drew a line between the missing of the struggle to end apartheid, and the far larger category of missing and dead associated with 'everyday' apartheid, notably displaced persons and unidentified migrant deaths. Because our work involves a specific engagement with the TRC and the MPTT, we do not name the missing dead of whom we write as 'apartheid-era missing dead', but rather the 'dead of apartheid-era atrocities'. Following the focus of the MPTT, this includes all those reported missing to the TRC (not only the 'disappeared') during the anti-apartheid struggle, and it includes those rendered missing or 'disappeared' by the liberation movements.

Histories of empire and conquest produced specific systems of legal and historical classification, as part of systems of governmentality and knowability. The category bushman was created out of histories of the dispossession and genocide of Khoesan people in the eighteenth century, that turned survivors into economic refugees on the edges of colonial agriculture and mission stations. ${ }^{30}$ Dispossession and immiseration became hallmarks of essentialised hunter-gatherers, whose traces were made 
knowable through archaeological and philological research, as part of an invented Palaeolithic in southern Africa, and through a legacy of folklore research. ${ }^{31}$ But the key discipline, in the academy and museums, propagating the knowability of the bushman as a body 'out of time' was physical anthropology. This placed collections of mortal remains into research environments that were centred on race and evolution, while subjecting them to typological classification and the preservationist logics of care and stewardship.

These ontological, legal and historical categorisations are all, as Edkins reminds us, profoundly political, resting on forms of governmentality (and erasure) that focus not on who the missing are (each individuated, irreplaceable 'person-as-such') but what they were. ${ }^{32}$ What they were, in turn, enables classification and categorisation - always processes of inclusion and exclusion. Naming, as Rinaldo Walcott, Corinne Kratz and Lauren van der Rede show (this issue), is deeply inflected by temporal and geo-spatial political histories. If the millions enslaved during the slave trade overwhelm in their sheer number, thinking this as a process of missingness translates each captive into a singular person who went missing and was/is missed. Similarly, lynching, as Kratz (this issue) suggests, involves a 'disappearance', even if the modus operandi is to reveal rather than conceal the bodies.

What would become visible if we were to name lynching as a 'disappearance', or, conversely, 'disappearances' as some form of lynching? Or as Walcott proposes (this issue), how might we 'think the Atlantic Ocean as a (crime) scene'? For one, it forcefully poses disciplinary boundaries: 'disappearance' via enforced disappearance is located in law's lexicon; lynching or the Middle Passage, although equally forms of 'disappearing' and murder, are located in the lexicon of political violence and thus politics, and/or history. Mahmood Mamdani, in a different context, points to how the lexicon of international human rights and humanitarian law simplifies, while that of politics invokes complexity and messiness. The former demands legal intervention; the supposed complexity and slipperiness of the latter evades clear lines of responsibility. Thus, naming is also about accountability for violence and its remedy. ${ }^{33}$ Here, we acknowledge our own somewhat historicist reference to colonial and apartheidera atrocities, which occludes racialisation's continuities, just as Suren Pillay argues that to talk of apartheid-era counterinsurgency is to occlude continuities with colonial conquest. ${ }^{34}$ Such divisions also uphold temporal separations between colonial, apartheid and post-apartheid timeframes, thus eliding the colonial and apartheid present.

Yet, the politics of reparation and return have strained at the borders imposed by these forms of categorisation. Wilfully scrambling temporalities and spatialities,

31 N. Shepherd, The Mirror in the Ground: Archaeology, Photography and the Making of a Disciplinary Archive (Johannesburg: Jonathan Ball, 2015).

32 Edkins, Missing, viii, 196

33 M. Mamdani, 'The Politics of Naming: Genocide, Civil War, Insurgency', London Review of Books, 29, 5, 8 March 2007, 5-8.

34 S. Pillay, 'The Partisan's Violence, Law and Apartheid: The Assassination of Matthew Goniwe and the Cradock Four' (PhD dissertation, Columbia University, 2011). 
activists and communities increasingly extend their demands for repair and return to present and past injustices. These demands are entangled in current politics and often form part of a wider struggle, not just for the unjustly dead and missed to be counted, but for those missing and missed in present-day politics. ${ }^{35}$

What makes for the inscription of the dead into the nation? For Verdery, as Moosage underscores, to ask 'what in present and past contexts gives what multiplicity of meanings to the résumé of [a] particular corpse' is productive as it points to 'how his complex biography make[s] him a good instrument for revising history' and 'what in his manifold activities encourages identification from a variety of people?' Asking and answering such questions, for Verdery, 'will often, but not always, elucidate why some dead bodies rather than others become useful political symbols in transitional moments. ${ }^{36}$ Here we note that most TRC and MPTT exhumations have been of former combatants, or those associated with other forms of organised political resistance (rather than, for example, deaths in inter-civilian violence), and are thus available to the post-liberation-movement state, as Van Laun shows (this issue) in her discussion of MPTT exhumations of executed political prisoners. Rousseau has written about the particular script of reburial, which draws on longer histories of the political funeral and its transfer, in the early 1990s, to the more ceremonial and official forms of a nation-to-be. ${ }^{37}$ Where political funerals sought to mobilise resistance, these more official funerals sought to pay homage to those who 'died for our freedom, and on whose deaths the post-apartheid nation is made to rest. This script has been adopted when reburying the missing dead; it also extends to multiple ceremonial moments, incorporating the missing dead into state rituals and intensifying the production of narratives of nation.

Significant aspects of this script are replicated with regard to skeletons of empire. Although, perhaps not as readily available for the kind of heroic inscription as those from the apartheid era, these remains were, from the very moment of collection, implicated in an earlier moment of nation-building. Through the acquisition of skeletons and a simultaneous project of making body casts of people deemed to be part of disappearing 'fossil races', the South African Museum established itself as a modern, scientific museum, adopting the procedures of classification prevalent in Europe. The confluence of this process with the founding of the Union of South Africa (in 1910) suggests a founding moment not just for the modern museum in South Africa, but for the new state itself. If this founding moment marked the emergence of 'white' South Africa, then the contemporary repatriation of human remains is similarly implicated in the making of the post-apartheid nation, and the associated transformation of the museum of the 'white' nation. ${ }^{38}$ This makes the museum an important site to reckon

Verdery cited in Moosage, 'Missing-ness', 124-125.

37 N. Rousseau, 'Identification, Politics, Disciplines: Missing Persons and Colonial Skeletons in South Africa' in E. Anstett and J.-M. Dreyfus (eds.), Human Remains and Identification: Mass Violence, Genocide, and the 'Forensic Turn' (Manchester: Manchester University Press, 2015). See also P. Hayes, 'Refusal of Light: Photography, History and Political Funerals in 1980s South Africa', paper presented to the 'Missing and Missed' workshop, 29 February-1 March 2018, UWC, Cape Town.

38 Rassool, 'Re-storing Skeletons'; L. Witz, G. Minkley and C. Rassool, Unsettled History: Making South African Pasts (Ann Arbor, MI: University of Michigan Press, 2017). 
with. It intersects with Rassool's long engagement with the museum as a key site of public history and epistemic formation. Indeed, museum practices are discussed by several contributors in this issue: Roque considers forms of classification of human remains; Van der Rede (on the Red Terror Museum in Ethiopia) and Van Laun (on South Africa's Gallows Museum) think about museums dedicated to the afterlives of violence; Kratz describes re/humanisation through exhibition design.

However, it is through practices of return and reburial that the skeletons of empire encounter the particular script of reburial associated with the missing dead of apartheid-era atrocities, and the politics of reparation and nation-building. One effect of this encounter is to underscore the post-apartheid state's failure to account for colonial atrocities through the TRC, given South Africa's history as a colonising power in Namibia, and even as an 'empire. ${ }^{39}$ Yet, while this challenged those nationbuilding efforts that do not account for longer legacies of harm that are still manifest in the colonial present, other effects have been to draw the dead bodies of both closer to the nation. While skeletons of empire exemplify (what Ricardo Roque, this issue, names as) raciologies that undergird South Africa's histories of racial subjugation, missing political activists and combatants are construed as those who died in the struggle to end apartheid.

This is unsurprising: returning human remains through exhuming or repatriating in South Africa has always been a state project. Both are directed and mediated by state agencies, as is the formal handover of remains to families and/or 'source communities. The state initiated the TRC, and the MPTT is located within the country's National Prosecuting Authority. This is unlike other settings, where exhumation teams tend to exist outside the state's boundaries. Similarly, repatriating skeletal remains in museum collections happens under the aegis of South Africa's Department of Arts and Culture. Although in the case of the missing dead of apartheid atrocities, political parties and families take charge of subsequent processes of reburial, representatives from government are frequently present. Further, until the more recent focus on executed political prisoners (see Van Laun, this issue), the MPTT mostly exhumed ANC cadres for whom a political biography was already in place, and who were thus easily available for appropriation. This is not the case with colonial era remains, who were politicised not in life but in their afterlives as specimens of racial science, yet it is as such that they become available for appropriation into a nationbuilding project. The post-apartheid government has also intervened with regard to black soldiers who died in World War I and II. In France and Belgium, for example, the South African government has embarked on projects of desegregation, exhuming the bodies of black soldiers killed on the Somme and reburying them in cemeteries alongside their white compatriots. ${ }^{40}$ Black soldiers who drowned in the sinking of the

39 D. Henrichsen, G. Miescher, C. Rassool and L. Rizzo, 'Rethinking Empire in Southern Africa', Journal of Southern African Studies (Special Issue on The South African Empire), 41, 3, June 2015, 431-435.

40 See 'South Africa Honours Black Soldiers Killed in WWI', Al Jazeera News, 8 July 2016, https://www.aljazeera.com/news/2016/07/ africa-honours-black-soldiers-killed-world-war-160708162350989.html (accessed 23 January 2019). 
Mendi during World War I have similarly been celebrated and memorialised. ${ }^{41}$ Such ceremonial moments do more than respect the places of death, or posthumously repair racial harm; they inscribe the dead as ancestors of a new post-apartheid nation. ${ }^{42}$

We must caution against overstating the role of the state's agency in these nationbuilding scripts as this occludes that of families, fellow comrades, activists and professionals, even the dead themselves. As scholars have noted, families' request for 'even one bone' to bury, frequently formulated in cultural terms, threaded through testimonies related to missing persons at the TRC, ${ }^{43}$ yet families have welcomed, even expected the heroic script of sacrifice to the nation. ${ }^{44}$ Rousseau suggests these moments are ones in which families are 'seen by a state' that has not yet delivered on its promises of 'a better life for all', and is therefore regarded as owing a debt to the dead, and by extension their families. ${ }^{45}$ Ex-combatants, whose very survival depends on state-provided military-veteran grants, also strongly support heroic funerals. They maintain a strong presence in politics and, following Fontein (this issue), it is possible to read ex-combatants' performative role at reburials as reflecting a political contest over who 'exercise[s] control over mortality'. Relatedly, demands for the repatriation of skeletons from museum collections have been deployed in identitarian politics and the construction of neo-Khoesan communities as well as claims to land and chieftaincy. ${ }^{46}$

Yet our representation of human remains appropriated into rituals of the nation, and the seeming desire of families, comrades or communities for exactly this national script, presents a picture that is too cynical. If families desire to be 'seen by the state', this is also a very human desire to make their dead seen and acknowledged - to make them count - just as ex-combatants are also driven by a sense of debt and loyalty to 'fallen comrades'. Similarly, while neo-Khoesan communities may find political capital in such moments, there is also, we suggest, a humble way in which people are coming to a funeral, whether it's big or small. They are there. That's where community is. The question should be, why is it that the only script available for mourning seems to be that of heroic death in the service of the nation or as a victim of raciology?

\section{Citizenship, re/humanisation and personhood}

'The status of being human', Keenan asserts (this issue), 'appears to be rather uncertain, unsecured and subject to regular challenge and contest. It is not guaranteed by anything but other humans, and we are not good at guarantees.' For colonial skeletons in museum collections, repatriation emphasises the return of humans, not objects; for the missing dead of apartheid era atrocities, both the TRC and MPTT

A. Erasmus, 'The Sound of War: Apartheid, Audibility and Resonance' (PhD Dissertation, University of the Western Cape, 2018), $108-143$.

42 Rassool, 'Re-storing Skeletons' and Rassool, 'Human Remains'.

43 M. Sanders, Ambiguities of Witnessing: Law and Literature in the Time of a Truth Commission (Johannesburg: Wits University Press, 2007).

44 J. D. Aronson, 'The Strengths and Limitations of South Africa's Search for Apartheid-Era Missing Persons', International Journal of Transitional Justice, 5, 2011, 262-281; Rousseau, 'Identification'.

45 Rousseau, 'Identification'.

46 Rassool, 'The Politics of Nonracialism'. 
have sought to identify remains through restoring names, and enabling burial rites. But such efforts to secure the human through practices of re/humanisation run up against the script of the hero and his (rarely female) appropriation by the nation. In elaborating this, we trace the contours of our reflections on re/humanisation and the associated concepts of citizenship and personhood.

Re/humanisation figures in both Rousseau and Rassool's work, yet our arrival at this concept was through different itineraries. While TRC witnesses testified to multiple ways in which dead bodies were dehumanised, Rousseau and Fullard's involvement in a continental network to address 'disappearances' underscored the ways in which this was not unique: Africa's missing tend to fall through grids of 'disappearances', and its dead are unaccounted for, 'existing in the public imagination of the rest of the world as faceless and nameless, mere suffering masses. ${ }^{47}$ For Fullard and Rousseau, this reflects wider philosophical and political issues relating to racialised global citizenship. ${ }^{48}$ Something about being named and made to count seems important. This much resonates with Edkins' framing of the 'person as such. ${ }^{49}$ But while contempt for, and the anonymity of, the black body in apartheid South Africa can be thought of, with Rancière (as Edkins would), as 'the part of no part', their work led to the MPTT's formation, and configured the tracing and returning of remains as part of an anti-racist citizenship project. Indeed, Fullard, quoted in Keenan (this issue), speaks of the MPTT as such.

This anti-racism can be considered as re/humanising, although the MPTT has not used this term. Influenced by rights' discourses in which the state's obligations in respect of missing and dead bodies of war and conflict were lodged, Fullard and Rouseau configured exhumation and reburial as symbolically conferring a posthumous citizenship. Edkins' notion of personhood works in opposition to statist projects of citizenship, yet, in that early and hopeful post-apartheid moment, the project of constituting a rights-bearing citizen had some traction. Later, Fullard and Rousseau saw public witnessing and mobilisation around issues of missing dead bodies across the globe as constituting what Engen Isin and Greg Nielsen call 'acts of citizenship' - a more agentive form of citizenship, the aim or effect of which is to 'challenge or rupture symbolic hierarchies or patterns of power. ${ }^{50}$ Here, in contrast to the path Keenan suggests, where the claim to be human enables the production of the citizen, for Fullard and Rousseau, it was in the citizen that the claim to be human could be lodged.

Rassool's itinerary to human remains and re/humanisation was through studies of how museums work, and how they can be remade outside the categories of modern citizenship. This happened first through his research on bushmanisation - the invention and reinvention of the bushman through genocide and subsequently by

\footnotetext{
47 Several scholars at the workshops - Nakanyike Musisi, Steve Davis, Nicky Rousseau, Martha Akawa and Jeremy Silvester presented papers on the politics of counting and naming the dead of conflict on the African continent.

8 MPTT cited in N. Rousseau, 'Eastern Cape Bloodlines 1: Assembling the Human', Parallax, 22, 2, $2016,211$.

49 Edkins, Missing, 2.

50 Cited in M. Fullard and N. Rousseau, 'Identities, Truth-Telling and Power: South Africa, Guatemala' in P. Arthur (ed.), Identities in Transition: Challenges for Transitional Justice in Divided Societies (New York: Cambridge University Press, 2011 ), 56.
} 
anthropology - assisted by critical scholarship that resisted hunter-gatherer tropes. ${ }^{51}$ As persons dehumanised in life, rendered as living fossils and thus as pre-human, bushmen in death were collected, defleshed (generally at the very site of disinterment), classified, studied and exhibited as objects of race, species and evolution, their mortal remains turned into racialised museum objects. A substantial number whose remains entered museums in South Africa and Europe, from locations in the northern Cape around the turn of the twentieth century, were recently dead, stolen from their graves through an illicit trade, and sometimes even 'bespoken for' prior to their deaths. ${ }^{52}$

Later, teaching the making of race took Rassool to physical anthropology's history, and the site of the museum as a field within this discipline. The South African Museum's project of making body casts of northern Cape farmworkers and shepherds for subsequent incorporation into a bushman diorama brought the body and the body cast into view, both as an artefact of race and as part of a genealogy of display. ${ }^{53}$ Rassool and Legassick further uncovered evidence of a history of collecting human remains (from around 1907 to 1908) in museum accession registers - a trail which led them en passant to the museums and laboratories of Europe, where these remains had been conscripted by racial science. ${ }^{54}$

While Legassick and Rassool's work sought to build an argument for the return and restitution of human remains from South African museums as part of their democratisation, it was also an early contribution to the field of museum restitution and the worldwide movement advocating for the return of skeletons and artefacts. The notion of re/humanisation, for Rassool, thus emerged through histories of dehumanisation. The strategic argument of return as rehumanisation mounted in negotiations that led to the remains of Klaas and Trooi Pienaar being repatriated from the Natural History Museum in Vienna and subsequently reburied in the Northern Cape, thus stood against multiple layers of violent dehumanisation. So, to think re/ humanisation means to reckon with those practices and processes that sought to erase the human.

Relatedly, acts of torture and elimination in the apartheid era rested on deep histories of colonial dehumanisation, in which African people were made 'tribal' or ethnic, governed through a legal order of subject and subjection, and apparently made knowable through scholarly disciplines. If colonial and apartheid raciologies constructed a hierarchy in which only white people were fully human, then political struggle constitutes a refusal to be so categorised and named. Claiming to be a political subject rendered racialisation insufficient, generating new conditions for dehumanisation: in desubjectifying the political subject, apartheid sought to produce

51 R. Gordon, The Bushman Myth: The Making of a Namibian Underclass (Boulder, CO: Westview Press, 1992); E. N. Wilmsen, Land Filled with Flies: A Political Economy of the Kalahari (Chicago: University of Chicago Press, 1989).

52 Legassick and Rassool, Skeletons.

53 C. Rassool and L. Witz, "South Africa: A World in One Country": Moments in International Tourist Encounters with Wildlife, the Primitive and the Modern', Cahiers detudes africaines, 143, 36 (3), 1996, 335-371; C. Rassool and P. Hayes, 'Science and the Spectacle: /Khanako's South Africa, 1936-7' in W. Woodward, P. Hayes and G. Minkley (eds), Deep Histories: Gender and Colonialism in Africa (Amsterdam: Rodopi, 2002).

Rassool, 'Re-storing Skeletons'. 
an absolute enemy, assigning categories such as 'terrorist' or 'communist proxy'. Yet in the latter, the sting of race returned as the black political subject was represented as 'manipulated' or 'captured' by 'white communists'; as proxy, the black political subject was rendered incapable of thinking and acting independently. Further, following Anstett and Dreyfus, ${ }^{55}$ death did not mark the end of the perpetrators' work: dehumanisation extends beyond death - 'disappeared' bodies were thrown down a bushy precipice or into crocodile-infested rivers, exploded as if they had 'blown themselves up', burnt on a fire or buried in secret unmarked graves. ${ }^{56}$

These practices of dehumanisation led us to question whether exhumation and/ or repatriation and return should be described as humanisation or rehumanisation. For those responsible for such dehumanisation, the persons whom they 'disappeared', or whose mortal remains they collected for racial science, were less than human and thus require humanisation. Failing to acknowledge this, and to talk only of rehumanisation obliterates the agencies of those responsible for dehumanisation, and the extent to which this was socially entrenched and normalised. Conversely (even if enslaved and regarded as mere property, racialised or ethnicised, deemed to be terrorists or communist proxies), to themselves and their families, comrades and communities, they were always human. For this reason, we speak of re/humanisation.

Erasing the human is never complete or, as Weizman and Keenan put it, 'Human remains are ... the kind of things from which the trace of the living subject cannot be easily erased - it lingers and haunts it..$^{57}$

Could we consider the 'little histories' suggested by Roque (this issue) as historiographical operations seeking to shore up science's instability (thus implicating history in racial science), as also directed at erasing the way humans cling to mortal remains, and thus as essential for the transformation from human into specimen? In short, to study human remains required removing the human, the 'person as such', as well as all familiarity and similarity with the scientist. Relatedly, the very practices of 'disappearing' and concealment testify to perpetrators' inability to kill openly and leave bodies where they fall, and thus to the persistence of the human and the limits of erasure..$^{58}$

Indeed, for the most part, bodies of the missing dead of apartheid atrocities entered death's routine bureaucracy. Sylvia Karl would perhaps see the necessity to bury in a grave as a triumph, demonstrating that re/humanisation closely follows dehumanisation. ${ }^{59}$ Even so, while burial in a grave secures the human, this may be temporary or partial. Being buried in an unmarked grave as a nameless pauper (a frequent practice) or remaining the state's property, as Van Laun shows (this issue) with

55 Anstett and Dreyfus, 'Why Exhume? Why Identify?'.

56 N. Rousseau, 'Death and Dismemberment: The Body and Counter-Revolutionary Warfare in Apartheid South Africa' in E. Anstett and J.-M. Dreyfus (eds), Destruction and Human Remains: Disposal and Concealment in Genocide and Mass Violence (Manchester: Manchester University Press, 2014), 204-225.

57 Keenan and Weizman, Mengele's Skull, 70.

58 D. Posel and P. Gupta, 'Introduction: The Life of the Corpse: Framing Reflections and Questions', African Studies, 68, 3, December 2009, 299-309; see also N. Rousseau, 'The Farm, the River and the Picnic Spot: Topographies of Terror', African Studies, 68, 3 , December 2009, 351-369, at 357.

59 S. Karl, 'Rehumanizing the Disappeared: Spaces of Memory in Mexico and the Liminality of Transitional Justice', American Quarterly, 66, 3, September 2014, 727-748. 
respect to executed prisoners, dehumanises once again. The proximity, perhaps even commingling of these categories - humanisation-dehumanisation-rehumanisation - points to their instability. The repeated oscillation between dehumanisation and rehumanisation arises precisely because of the persistence of a politics in which to be human is tied to the politics of the Enlightenment, whereby our very existence is tethered to its negative - those 'sexualized, racialized, and naturalised others, who are reduced to the less than human status of disposable bodies' as Rosa Braidotti puts it. Within such politics, Braidotti continues, 'we are all humans, but some of us are just more mortal than others.' ${ }^{60}$

Returning to Keenan (this issue), if 'we are not self-evidently human' then re/ humanisation is one strategy we can use to make that claim. And as with dehumanisation, re/humanisation requires practices and techniques. If following Karl, re/ humanisation begins with someone seeking the missing, this suggests that human instability is always a relational question. Responding to this question in the case of a missing dead body, whose person can no longer make that claim for themselves, requires not just being missing, but being missed - in short, a person or community who misses the missing.

Practices of consulting with families, or in cases of repatriation, what Rassool calls 'cultural consultations' to establish family or kinship ties, are similarly re/humanising. This work is also evident during exhumations, and in the many interactions between mortal remains and those working with them. For example, at a grave where the MPTT positions a poster with the person's name and photograph, that functions not just as a marker but almost, as Van Laun notes (this issue), as a temporary headstone. Or, in a grave itself, where, from a heap of bones, a body for mourning is produced through the small acts of carefully handling and identifying each bone, and later in the laboratory carefully laying out the bones in anatomical order. ${ }^{61}$ Such practices are all directed at returning mortal remains to a social network - familial, other forms of community, even perhaps the community of nation - suggesting that the question of the social is key in re/humanising. To do this requires the single most important practice of re/humanisation - the restoring of a name, identification. This, in turn, requires an osteobiography, and this particular 'process of re-humanisation and restoring of personhood is materially enacted' through disciplinary knowledges 'mediated by the discourse of forensics. ${ }^{62}$ Yet it is physical anthropology which, as Rassool underscores, carries the legacies of colonial and racial violence, and for this reason, the forensic examination of the skeletons of empire has been disallowed in South Africa.

Exhumation surfaces not just mortal remains but artefacts too. 'Grave goods' are often intimate and personal. Coins, a key, a ring, fragments of underwear, a sock, a shoelace, often evoke not just the human but the very person being sought. As such,

60 R. Braidotti, 'Working Towards the Posthumanities', Transhumanities, 7, 1, 2014, 155-175, at 162.

61 Rousseau, 'Eastern Cape Bloodlines', 208-213.

62 Moosage, 'Missing-ness', 136. 
these become critical assemblages to personhood as well as to re/humanising remains for families. ${ }^{63}$ Moreover, forensic teams sometimes fail to recover distinguishable human remains. When 'just one bone to bury' is no longer retrievable, the MPTT has held spiritual repatriations. In instances where remains have disintegrated over time, or been burnt and irretrievably commingled with charcoal and other bodies, soil or bone fragments and charcoal have been collected from the site, provoking us to ask, what constitutes a human, and are such practices merely symbolic? Following Fontein's emphasis on the body's permeability, leakiness and stickiness, is such charcoal or soil in some way as human as cremains, and thus also re/humanising? Or, as Ewa Domanska proposes, is this living matter that extends life? ${ }^{64}$

In some senses Domanska directs us towards rethinking the human, as does Sheikh (this issue), relocating us in a different ontology and politics of 'more-thanhuman socialities, between the human and nonhuman.' Echoing some of Sheikh's position, Fullard (this issue) notes of the human skeleton:

His bones radiate out from the vertebrae of his spine. The vertebral column is the connective tissue we share with fish and fowl, mammal and lizard. Here I see our animal place, a mutual architecture built over millions of years.

The erosion of his umber brown bones ... is slowly bringing him closer in appearance and substance to the roots and soil we plucked him from. Decomposition returns us to our affinities with flora and fauna. He is becoming earth.

While we are to varying degrees in sympathy with this move, many of the practices of dehumanisation have rested on tropes of animality, particularly in association with beings most closely related to humans - monkey, baboon, gorilla. These are not just historical practices, they persist with regularity in contemporary South Africa. As Sheikh (this issue) herself raises, how do we think the project of the posthuman in such brutal contexts?

Extending the 'more-than-human', Rassool argues that artefacts associated with skeletons of empire are like missing persons: ancestral, intimately linked with the dead, sometimes the very objects that accompanied the dead on their journey by ox-wagon were then shipped to Europe. In one instance, such artefacts include four engraved rocks, chopped from the earth as part of the same collecting expedition. Accordingly, the rocks come to stand almost equally as the remains of missing ancestors. ${ }^{65}$ Conceptually and anthropologically part of the same collecting effort,

63 Renshaw, Exhuming Loss.

64 E. Domanska, 'Dehumanisation Through Decomposition and the Force of Law' in Z. Dziuban (ed.) Mapping the 'Forensic Turn' (Vienna: New Academic Press, 2017), 89-106.

65 L. Förster, 'Provenance: An Essay Based on a Panel with Ciraj Rassool, Paul Basu and Britta Lange' in Centre for Anthropological Research on Museums and Heritage (CARMAH), Otherwise: Rethinking Museums and Heritage, CARMAH Paper 1, Berlin, 2017, http://www.carmah.berlin/wp-content/uploads/2017/10/Carmah_Paper-1.pdf (accessed 19 January 2019). 
artefacts are separated when they enter a museum, where they are placed in different collections and made subject to different disciplines and governmentalities. Can we think of these objects as ancestors, as living people, embodiments or extensions of those who are missed? More than traces, they are perhaps, as Taylor suggests (this issue) 'simultaneously themselves and something else' or as Sheikh (this issue) calls the 'more-than-human'.

While the above observations have been made across different geo-spatial settings, a distinguishing feature of exhumations and repatriations in South Africa are those practices of re/humanisation associated with burial rituals after exhumation and identification, namely the handover of remains and subsequent reburial. Again re/humanising leans on material objects, most notably the coffin. Apartheid- and colonial-era remains - even where they cannot be described as a body, where there are only fragments, not even a shred of DNA - are placed in a coffin, thus rendering the fragments as whole, as a body, a person, and evoking the power of being in the presence of the dead. Where available, a poster-size photograph of the person, often framed, is placed on the coffin. If the coffin represents the integrity of the person, handovers and reburials do further work to publicly return the person to social networks, just as the processes of community consultation already mentioned do in a quieter way.

More than anything, as both Rousseau and Rassool have underscored through various examples, it is in the handover and reburial that the extent to which re/ humanising is entangled with necropolitics is evident. For this reason, the project of re/humanising requires further scrutiny.

For Rassool, not only does re/humanising extend a dead person's biography, it incorporates the person into the 'narrative of the making of democracy, whose telling might be part of a public history geared towards citizen formation. ${ }^{66}$ For Moosage, however, this presupposes a certain kind of personhood shaped to fit the script. ${ }^{67}$ With regard to the missing dead of apartheid atrocities, the kind of personhood presupposed is that inscribed within the particular biographic narrative of a liberationstruggle activist. Previously, Rassool has proposed that, since physical anthropology had dehumanised skeletons of empire, history was 'a more appropriate discipline of the dead in the twenty-first century', and indeed it is history that provides the presupposed biography of the dead. Yet, as Rassool now recognises, where history has been deployed in memorialisation practices, especially at Freedom Park, it offers up

the dead of South Africa's liberation struggle [as] ancestral heroes to the nation [drawing the missing dead] into a post-apartheid politics of African indigeneity rooted in familiar colonial categories of tribe and sometimes 
even race. It was as if the colonial categories were never too far away in rethinking the bones of South Africa's dead. ${ }^{68}$

If this is the case, Moosage suggests, whether history is 'put to use, or abuse', its role in re/humanisation seems to have intensified the script of nation, while being equally freighted with colonial legacies. ${ }^{69}$ Nevertheless, Rassool argues that it is imperative to restore the human in order to challenge both the original turning of humans into fossils and objects, and their ongoing normative inscription as objects in collections. While recognising that 'it was the nation that constructed the framework for the return as a "re-patriation" directed towards "national healing" and "social cohesion"', Rassool contends that return is 'more than a physical movement to [an] original place of life, death and burial', as well as one in which the skeletons of empire acquire 'post-mortem personhood'. This post-mortem personhood turns them into humans, and, Rassool contends, into 'subjects of history.' ${ }^{70}$

Whereas the script of the heroic liberation fighter overdetermines the missing dead (or, as Edkins might put it, focuses more on what rather than who they were), Moosage suggests that specific kinds of personhood are not presupposed as much for the colonial-era dead. ${ }^{71}$ At the same time, where current repatriation practices transform skeletons of empire from 'objects of race' to 'subjects of history', they nonetheless 'became significant to the nation ... [taking] their place as part of the categories of the dead that constituted South Africa's memorial complex' ${ }^{72}$

Furthermore, as Moosage argues, personhood for Rassool is tightly bound to the return of named people whose lives could be narrated biographically. This is somewhat ironic, as Rassool's earlier work critiqued conventional biography and its chronological narratives, instating instead a disputatious and contested field of biographic production. ${ }^{73}$ Nonetheless, the strategy of re/humanisation has returned him to the biographical, reconstructing the biographies of individuals who can be named and about whom evidence of their lives and families exists. Seeking to re/humanise generates a profound desire to render coherent persons subjected to disruption in life and who, in death, were inserted into a racial history; to return not just the remains but the person, the human. For Moosage, however, biographies which seek to replace those that have been stolen are limited. For colonial remains, little more than the bare dates remain - death, theft, departure from South Africa, entry into European museums. The TRC and MPTT require a little more: pre-mortem information (birth, stature, dental and medical histories, and so forth), political affiliation, date and circumstances of going missing, subsequent fate and date and cause of death. Thus, it is the racialised skeleton of empire or struggle hero that is required for handover

68 Rassool, 'Human Remains', 156, 145.

69 Moosage, 'Missing-ness', 141.

70 Rassool, 'Re-storing Skeletons', 669.

71 Moosage, 'Missing-ness', 140.

72 Rassool, 'Re-storing Skeletons', 669.

73 See particularly, C. Rassool, 'The Individual, Auto/biography and History in South Africa' (PhD Thesis, University of the Western Cape, 2004). 
and reburial. For Rassool, it was through their inscription into a biography that skeletons of empire were transformed from 'objects of race' into 'subjects of history'. Yet, Moosage points out, in becoming a subject of history one also becomes subject to history. ${ }^{74}$

\section{Missing-ness}

Rassool and Rousseau concur that re/humanising the dead from colonial museum collections, and from the scattered disposal sites of the killing machines of apartheid, has proffered them to the nationalising tropes of apartheid and freedom, rendering them human through biographic narrations of state protocol and governmentality. In short, the person remains missing. Physical absence thus becomes not the only marker of missingness but is replicated multiple times as the 'person is rendered through personal, social and political relations, ${ }^{75}$ including the very attempts to recover their mortal remains and restore their personhood. And yet, repurposing Taylor (this issue), 'each [return] must fail because it [can]not return the missing ... No matter how deft ... it fail[s] to repair an irrecoverable loss.' Beyond failure, we are in agreement about the limits of recovery. ${ }^{76}$

Indeed, Edkins renders missingness to index the ways in which being made missing and the condition of being missing has social and political implications. Missingness - or missing-ness, as Moosage glosses it to indicate both the act of being made missing, and the processes of being missed - is a condition of absence, a lacuna, the very nature of which is one of uncertainty and undecidability, both a space that cannot be filled and an excess that cannot be contained. While for Edkins 'that very "missingness" ... makes the person irreplaceable', Moosage sees an inherent potentiality that asks to be put to work. The person, if you like, is 'up for grabs' (recalling Sekula's notion of 'political maneuvering'), available for inscription and appropriation, and in ways that can only render the person missing yet again. ${ }^{77}$

Edkins' interest in missing persons is activated by her critique of contemporary forms of biopolitics, in which everyone is missing. She argues that 'the sovereignty of the nation-state, with its narratives of national identity' must be resisted as these narratives reproduce 'the same dehumanized and depoliticized subjects' who must remain missing. ${ }^{78} \mathrm{Her}$ interest in missing persons is precisely that the elusive and indeterminate condition of being missing exposes the limits of sovereignty: neither alive nor dead, the missing person cannot be governed. Following this, she argues that, in contemporary biopolitical regimes, it is only outside the binds of citizenship and the nation-state that a politics can exist in which each person - or the 'personas-such' - can count. This demand that every person counts is visible for Edkins in

\footnotetext{
Moosage, 'Missing-ness', 146.

Moosage, 'Missing-ness', 33.

Rousseau, 'Eastern Cape Bloodlines'.

Moosage, 'Missing-ness', 46-48.

J. Edkins, 'Humanitarianism, Humanity, Human', Journal of Human Rights, 2, 2, 2013, 253-258, at 256.
} 
displays of photographs of missing persons - a practice adopted by Argentina's Madres de Plaza de Mayo, and replicated in numerous contexts thereafter.

[These photographs] threaten to reveal the lack and excess around which the symbolic or social order is structured, and which must be concealed for that order to hold. When survivors of traumatic events such as wars refuse to narrate those events in terms of heroism and sacrifice for the nation state but insist on encircling the trauma, the order of sovereign power is challenged ... the photograph, or the face in the photograph, has the potential to destabilize. ${ }^{79}$

Research and investigation into missing persons always reveals both less and more, never enough and yet far more than is desired. This information may re/humanise, yet as Eric Steiner Carlson found in his attempt to write the biography of a desaparecida, 'Julia', his careful interviews with her family, friends and comrades produced not a singular person but a bewildering, frequently contradictory, multitude of persona ${ }^{80}$ The person-as-such refuses to be pinned down, or as Edkins has argued 'is always the subject of a lack, never complete, always relational, never fully known, never "at home."'81 It is this that makes the photographs so powerful. A photograph as portrait or mugshot, like all photographs, exceeds the intention of its taking, and similarly cannot be mastered or pinned down. To extend this thought suggests a strategy of re/humanisation that insists on the loss of each and every person without attempting to fill the space of absence - an insistence on personhood outside of biographical narration, where a photograph alone, a face, held or posted by those for whom s/he is missed, does the work of re/humanisation.

For Moosage, this may not be enough. Missing-ness - like the ontological dilemma of alive or dead - is located in the interstices of presence and absence, knowing and not knowing, an uncertainty that runs through iterations of the work of evidence and mourning. The implications for him are, counterintuitively, to hold onto 'its elusiveness' rather than naming it so as to define it, and to scrupulously mark 'the contours of discourses ... [that] it simultaneously touches upon and is constitutive of.' For him, the work of history is to trace 'the modes through which missing persons in South Africa emerge and are figured through various discursive strategies constituted by/through apartheid's [and colonial] violence and iterations thereof'. In so doing, the work of politics is to abide by missing-ness through asserting its potential, while 'working through' (and with) the conditions that elude any attempt to master missing-ness. ${ }^{82}$

In finishing but not concluding, we agree to not be hasty in wanting to provide answers to the dilemmas raised, several of which were provoked by contributors to

J. Edkins, 'Politics and Personhood: Reflections on the Portrait Photograph', Alternatives: Global, Local, Political, 38, 3, 2013, 149-150.

80 E. S. Carlson, I Remember Julia: Voices of the Disappeared (Philadelphia, PA: Temple University Press, 1996).

81 Edkins, Missing, 11

82 Moosage, 'Missing-ness', 234-284; 36-37. 
this issue. We choose instead to pose them as questions, holding onto their uncertainty and provisionality, in an attempt to extend Walcott's evocation (this issue), of holding onto 'the detail of a past that is no longer [but, we would add, is at the very same time still] present in an effort to make ... a site for the possibility of life and living.'

In conceptualising the two workshops, held in February and March 2018, we sought to retain the productivity of placing the unsettled and missing dead of apartheid-era atrocities and the skeletons of empire alongside each other. We sought to take insights from this unique connection into conversations with other sites of the unsettled and missing dead to try to understand whether engaging with multiple geo-political settings might elaborate a range of conceptual questions to which the afterlives of missing and missed bodies point. The scholars we invited were those whose work we had read, or who work with some of the concepts central to our project - personhood, agency, political afterlives, re/humanisation. This included scholars who have not focused on questions of the dead and the identification of human remains, but whose philosophical or aesthetic contributions intensified our engagements with the missing - and even, as Taylor suggests (this issue), which 'agitate one another'.

Such contributions included scholarly papers (some of which appear here), a 'Sites of Missingness' tour through Cape Town convened by Heidi Grunebaum, a screening of Nadia Davids and Jay Pather's play, What Remains, film clips by Chowra Makeremi and Premesh Lalu, an interactive art installation by Emma Minkley - whose artwork also features on the cover of this issue - and a reading by Fullard from her forthcoming book. Consequently, the reader of this special issue of Kronos will encounter a range of contributions, some of which seem to push the limits of the theme 'Missing and Missed' in ways that we hope will prove fruitful. Moreover, longtime readers of Kronos may be surprised at the range of articles that focus on contexts outside of southern Africa, as well as the form of several of these contributions which, alongside scholarly articles, include artwork (Minkley), philosophical and reflective essays in cultural analysis (Taylor and Walcott), and creative non-fiction (Fullard). We hope you will find what follows as provocative and productive as we have. 